\title{
OCCURRENCE AND CHARACTERISTICS OF VIRULENCE GENES OF ESCHERICHIA COLI STRAINS ISOLATED FROM HEALTHY DAIRY COWS IN INNER MONGOLIA, CHINA
}

\author{
Simujide Huasai ${ }^{1}$, Aorigele Chen ${ }^{1^{*}}$, Chun-jie Wang $^{2}, \mathrm{Yu} \mathrm{Li}^{1}$, Bai Tongrige ${ }^{1}$ \\ ${ }^{1}$ College of Animal Science, Inner Mongolia Agricultural University, Hohhot 010018, P. R. China; ${ }^{2}$ College of Veterinary \\ Medicine, Inner Mongolia Agricultural University, Hohhot 010018, P.R. China.
}

Submitted: October 15, 2010; Returned to authors for corrections: July 13, 2011; Approved: January 16, 2012.

\begin{abstract}
Virulence genes of Escherichia coli (E. coli) isolates from healthy dairy cows were identified and characterized by a multiplex PCR assay and serogrouping test. The results showed that among the target genes, eaeA was most frequently detected, accounting for $22.11 \%(67 / 303)$ in all strains from 101 cows. For categorization of $E$. coli, aEPEC was the category with widest distribution detected in $55(18.15 \%)$ strains from 22 cattle. All of 84 PCR-positive strains belonged to $14 \mathrm{O}$ serogroups, and O149 (25.00\%) was most common identified, followed by O2 (17.86\%), O8 (11.90\%) and O103 (9.52\%) with relatively high prevalence.
\end{abstract}

Key words: E. coli; Virulence gene; Multiplex PCR; Serogroup; Healthy dairy cow

\section{INTRODUCTION}

E. coli is an opportunistic species comprising the normal flora in the gastrointestinal tracts of the warm-blooded animals. It is usually non-pathogenic kept in host intestines. However, in the immunocompromised or intestinal flora disturbed hosts, or when the E. coli in the host intestines become translocated, normal E. coli strains can cause relevant diseases as a pathogenic one (1).

Pathogenic E. coli is increasingly isolated from cases of human and animal diseases $(2,3)$. Moreover, it has also been detected from healthy humans and animals. In 2001, Orden et al. (2001) (4) reported some causative agents (cytotoxic necrotizing factors, verotoxins and eae gene) of pathogenic $E$. coli in healthy cows, sheep and goats. Amar et al. (2007) (5) reported existence of enteroaggregative $E$. coli in asymptomatic individuals in England. Some researches in other countries also isolated pathogenic E. coli from healthy animals $(6,7)$. However, very few studies have examined the pathotypes of $E$. coli in healthy animals in China. In present study, the virulence genes of $E$. coli were investigated and characterized to elucidate the prevalence of pathogenic E. coli in healthy cattle.

PCR (Polymerase chain reaction) method, particularly multiplex PCR, being a rapid and effective gene detection assay, is increasingly popular in identification of various bacteria $(8,9)$. Some multiplex PCRs have been reported elsewhere to detect virulence genes of E. coli. Bai et al. (2010) 
(10) reported a multiplex PCR procedure that detected $f l i C$, stx 1, stx2, eae, $r f b E$, and hlyA genes, which are the major virulence genes of $E$. coli $\mathrm{O} 157: \mathrm{H} 7$. In the study conducted by Kwai and Ke (2009) (11), a multiplex PCR assay was applied to a panel of $87 \mathrm{E}$. coli isolates from different sources to simultaneously detect virulence genes, such as $s t 1, l t 1, l t 2, v t 1$, $v t 2$ and eaeA. Moreover, some researches focused on the detection of virulence genes in combination with serogroupspecific genes to test serogroups of $E$. coli using multiplex PCR methods $(12,13)$. We can effectively save time and effort involved in the determination of various virulence genes through multiplex PCR technique.

\section{MATERIALS AND METHODS}

\section{E. coli strains and control strains}

Forty unrelated family dairy farms in Hulunbeier area (Inner Mongolia, Northern China), were randomly selected for test. The population in this area is predominantly engaged in animal husbandry. Stool specimens were collected from the rectums of 212 apparently healthy dairy cows (20\% of the herd or a minimum of 5 cows from each farm). The specimens were transported on ice to the laboratory. Swabs of stool were inoculated onto the surface of eosin-methylene blue agars (EMB) and streaked for isolated colonies. After incubation for $24 \mathrm{~h}$ at $37{ }^{\circ} \mathrm{C}$, three or four colonies with typical E. coli morphology and one of another morphological type were streaked on fresh plates. Each colony was independently subjected to Gram staining, microscopic examination, biochemical test and serogrouping. Eventually, 303 E. coli strains from 101 cows (three strains for one cow), were randomly selected for characterizing virulence genes. E. coli strains used as controls were C83922 (O101:K99, F41; $\left.s t^{+}\right)$, C83902 (O8:K87, K88ac; st lt $^{+}$), E. coli O157 (stx $1^{+}$stx $\left.2^{+}\right)$, E. coli $\mathrm{O} 139\left(e a e^{+}\right)$and E. coli $\mathrm{O} 127\left(e a e A^{+} b f p A^{+}\right)$. All strains were stored at $-20{ }^{\circ} \mathrm{C}$ in LB broth with $10 \%$ glycerol.

\section{PCR protocols}

Bacterial DNA used for PCR analyses was prepared with a genomic DNA purification kit $\left(\right.$ Wizard $^{\circledR}$ Genomic DNA Purification kit, Promega Corporation, USA) used according to the manufacturer's recommendations. Alternatively, bacterial DNA was extracted by a boiling procedure. Single colonies were cultured overnight at $37^{\circ} \mathrm{C}$ in $1.5 \mathrm{ml}$ tubes containing $1 \mathrm{ml}$ LB broth. Each bacterial suspension was centrifuged for 15 min at $12,000 \mathrm{rpm}$, and the pellet was resuspended in $200 \mu \mathrm{l}$ double distilled water. After $10 \mathrm{~min}$ of boiling in a water bath and centrifugation for $15 \mathrm{~min}$ at $12,000 \mathrm{rpm}$, the supernatant was used as template DNA for PCR assays.

All strains were evaluated by multiplex PCR for identification of six virulence genes. The PCR primers were presented in Table 1. We consulted the references about the conditions for DNA template amplification and further optimized for present multiplex PCR procedures.

Table 1. PCR markers for detection of virulence gene of E. coli

\begin{tabular}{|c|c|c|c|}
\hline Target gene & Nucleotide sequence $\left(5^{\prime} \rightarrow 3^{\prime}\right)$ & Size of amplified product (bp) & References \\
\hline eaeA & $\begin{array}{l}\text { F: GTGGCGAATACTGGCGAGACT } \\
\text { R: CCCCATTCTTTTTCACCGTCG }\end{array}$ & 891 & 14 \\
\hline$b f p A$ & $\begin{array}{l}\text { F: AATGGTGCTTGCGCTTGCTGC } \\
\text { R: GCCGCTTTATCCAACCTGGTA }\end{array}$ & 326 & 14 \\
\hline stx 1 & $\begin{array}{l}\text { F: AAATCGCCATTCGTTGACTACTTCT } \\
\text { R: CAGTCGTCACTCACTGGTTTCATCA }\end{array}$ & 370 & 14 \\
\hline stx 2 & $\begin{array}{l}\text { F: TGCCATTCTGGCAACTCGCGATGCA } \\
\text { R: GGATCTTCTCCCCACTCTGACACC }\end{array}$ & 283 & 14 \\
\hline st & $\begin{array}{l}\text { F: ATTTTTCTTTCTGTATTGTCTT } \\
\text { R: CACCCGGTACAAGCAGGATT }\end{array}$ & 190 & 15 \\
\hline$l t$ & $\begin{array}{l}\text { F: GGC GAC AGA TTA TAC CGT GC } \\
\text { R: CGG TCT CTA TAT TCC CTG TT }\end{array}$ & 450 & 15 \\
\hline
\end{tabular}


Bacterial DNA was amplified in the PCR reaction mixtures as follows. Each reaction system had a final volume of $50 \mu 1$ and contained $2.0 \mu \mathrm{l}$ of $10 \times E_{X}$ Taq buffer, $4 \mu \mathrm{l}$ of $25 \mathrm{mM} \mathrm{MgCl}_{2}, 4 \mu \mathrm{l}$ of dNTPs (each $2.5 \mathrm{mM}$ ), 1.25U of $E_{X}$ Taq DNA polymerase, 20$40 \mu \mathrm{M}$ of each primer, and $2 \mu \mathrm{l}$ of the DNA template. All reagents were the products of TaKaRa Biotechnology (Dalian) Co., Ltd, China). The mixtures were preheated at $94^{\circ} \mathrm{C}$ for $1 \mathrm{~min}$ before submitted to recycling step. The amplification conditions for the multiplex PCR assays were 30 cycles at $94^{\circ} \mathrm{C}$ for $30 \mathrm{sec}, 55^{\circ} \mathrm{C}$ for $30 \mathrm{sec}$, and $72^{\circ} \mathrm{C}$ for $1 \mathrm{~min}$. A final extension step was performed at $72^{\circ} \mathrm{C}$ for $10 \mathrm{~min}$. The PCR products were kept at $4^{\circ} \mathrm{C}$ until removed and were separated in agarose gel $(2 \% \mathrm{w} / \mathrm{v})$ electrophoresis and visualized under UV light after staining with a nucleic acid stain (GoldView ${ }^{\mathrm{TM}}$, SBS Genetech, Beijing, China).

\section{Serogrouping}

Serological typing of all PCR-positive strains was carried out by slide agglutination with $E$. coli $\mathrm{O}$ antisera (O1-O160). The antisera were obtained from the China Institute of Veterinary Drug Control (Beijing, China).

\section{RESULTS}

Of 101 healthy dairy cows, 34 (33.66\%) carried at least one virulence gene of E. coli, and of 303 E. coli strains from all animals (three strains were tested for one animal), 84 (27.72\%) were positive for the virulence genes (Table 2, seen in page 16). Among the six virulence genes identified, eaeA was the most common gene harbored by 67 (22.11\%) strains from 27 cattle. The prevalence of the remaining genes was that $b f p A$ and $s t$ were both recovered in $10(3.30 \%)$ strains from four different cattle, $l t$ and stxl were in seven $(2.31 \%)$ strains from three cattle respectively and six $(0.94 \%)$ strains from three cattle, and none of the strains carried the gene for stx2 (Fig. 1).

Table 2. Distribution of virulence genes of $E$. coli isolates

\begin{tabular}{|c|c|c|c|c|c|c|c|c|}
\hline \multirow{2}{*}{ Serogroup } & \multicolumn{2}{|c|}{ No. of } & \multicolumn{6}{|c|}{ Virulence gene of $E$. coli } \\
\hline & Animals & Strains* & eaeA & $b f p A$ & stx 1 & stx 2 & st & lt \\
\hline $\mathrm{O} 2$ & 6 & 15 & + & - & - & - & - & - \\
\hline O8 & 3 & 7 & + & - & - & - & - & - \\
\hline O8 & 1 & 3 & - & - & - & - & - & + \\
\hline $\mathrm{O} 10$ & 2 & 5 & + & - & - & - & - & - \\
\hline $\mathrm{O} 44$ & 1 & 2 & - & + & - & - & - & - \\
\hline O55 & 1 & 3 & + & + & - & - & - & - \\
\hline $\mathrm{O} 78$ & 1 & 3 & - & - & - & - & + & - \\
\hline $\mathrm{O} 78$ & 1 & 3 & - & - & - & - & + & + \\
\hline O86 & 1 & 2 & + & - & + & - & - & - \\
\hline O86 & 1 & 3 & + & - & - & - & - & - \\
\hline O103 & 2 & 5 & + & + & - & - & - & - \\
\hline O103 & 1 & 3 & + & - & - & - & - & - \\
\hline O125 & 1 & 2 & - & - & + & - & - & - \\
\hline O136 & 1 & 3 & - & - & - & - & + & - \\
\hline $\mathrm{O} 145$ & 1 & 2 & + & - & + & - & - & - \\
\hline O149 & 8 & 21 & + & - & - & - & - & - \\
\hline O152 & 1 & 1 & + & - & - & - & - & - \\
\hline O159 & 1 & 1 & - & - & - & - & + & + \\
\hline
\end{tabular}

*: Three $E$. coli strains were tested for one animal. 


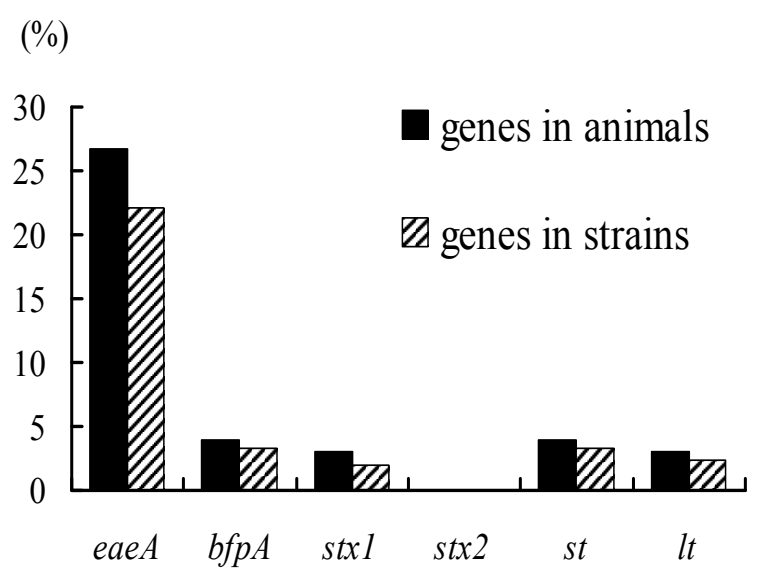

Figure 1. Frequency of virulence genes of $E$. coli isolates

$E$. coli isolates were categorized into enteropathogenic $E$. coli (EPEC), Shiga-toxin producing E. coli (STEC) and enterotoxigenic E. coli (ETEC), and EPEC was further divided into typical EPEC (tEPEC) and atypical EPEC (aEPEC) according to the related virulence genes detected by the multiplex PCR assays. The distribution of the categories according to priority was as follows: aEPEC detected in 55 $(18.15 \%)$ strains from 22 cattle, ETEC in 13 (4.29\%) strains from five cattle, tEPEC in eight $(2.64 \%)$ strains from three cattle, and STEC in six (1.98\%) strains from three cattle (Fig. 2). An example of the multiplex PCR products for representative isolates is shown in Fig. 3.

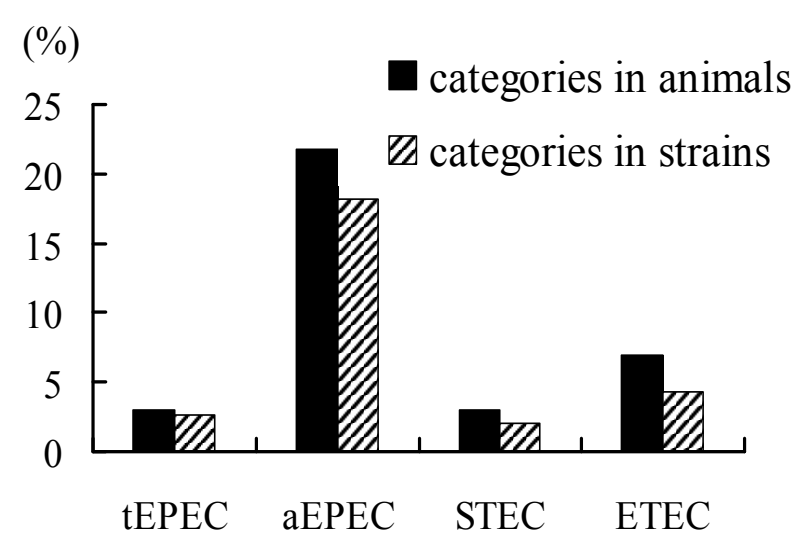

Figure 2. Frequency of categories of $E$. coli isolates

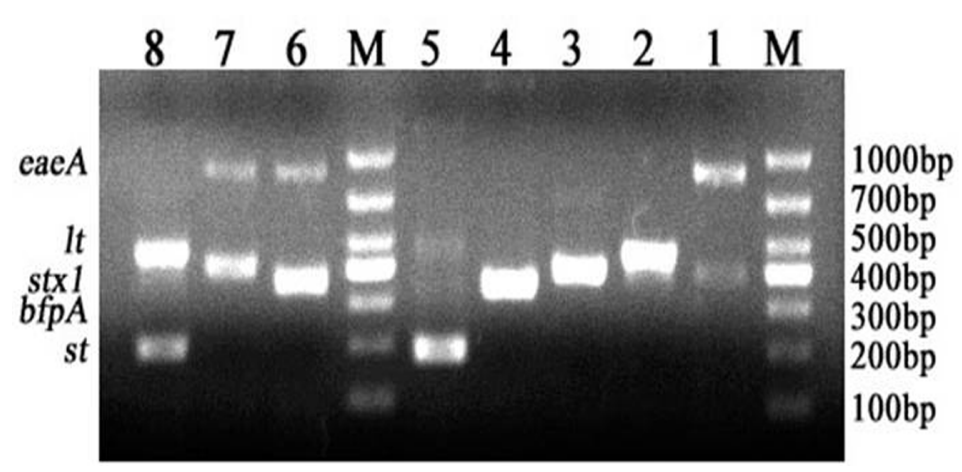

Figure 3. Multiplex PCR products for representative strains from aEPEC, tEPEC, STEC and ETEC. Lanes: M, DNA markers; 1, an aEPEC-strain only detected eaeA; 2, a ETECstrain only detected $l t ; 3$, a STEC-strain only detected $s t x 1 ; 4$, an aEPEC-strain only detected $b f p A ; 5$, a ETEC-strain only detected $s t ; 6$, an tEPEC-strain detected eaeA and $b f p A ; 7$, a STEC-strain detected eaeA and stx1; 8, a ETEC-strain detected lt and st.

Based on the serogrouping test, all of 84 PCR-positive strains covered $14 \mathrm{O}$ serogroups (Table 2 , seen in page 16). As shown in the table, O149 (25.00\%) was the most common serogroup, followed by O2 (17.86\%), O8 (11.90\%), O103 (9.52\%), O78 (7.14\%), O10 (5.95\%), O86 (5.95\%), O55 (3.57\%), O136 (3.57\%), O44 (2.38\%), O125 (2.38\%), O145 (2.38\%), O152 (1.19\%), and O159 (1.19\%).

\section{DISCUSSION}

Cattle have been considered as important asymptomatic carriers of potential risk factors for diseases of humans and animals. The present study has shown that key virulence genes of pathogenic $E$. coli could be identified in fecal $E$. coli isolates from healthy cattle in northern China. The virulence genes examined in this article were chosen because of their association with $E$. coli strains causing animal and human infections. Our findings showed that eaeA is the most common gene identified in $22.11 \%(67 / 303)$ strains, whereas the frequency of the other test genes is generally less than $4 \%$ 
(Table 2). Moreover, in the 67 eaeA-positive strains, only 12 (17.91\%) were found the combination of eaeA with other genes; the rest 55 strains were recovered eaeA alone (Table 2, seen in page 16). The above results were the main reason for why aEPEC was the most frequent one among the four categories tested. In our study, E. coli strains possessed A/E genotype $(e a e A+)$ or EAF plasmid $(b f p A+)$ were classified as atypical EPEC (aEPEC), while the strains with both of them were as typical EPEC (tEPEC) regardless of their serogroups. For the other categories, the strains with and without the eaeA genotype that harbored Shiga toxin genes (stx1 and/or stx2) were classified as STEC; the strains harbored enterotoxins ( $s t$ and/or $l t$ ) were as ETEC. The aEPEC is increasingly isolated from human and different animal species, and domestic animals have been seen as important reservoir of aEPEC. Krause et al. (2005) (16) reported prevalence of aEPEC as high as $92.8 \%$ in attaching and effacing Escherichia coli (AEEC) strains (equivalent to eae-positive $E$. coli strains in current article) from healthy animals when testing seven different species of domestic animals. Yuste et al. (2008) (17) described 166 of 185 AEEC strains that isolated from diarrheic calves, lambs, and goat kids and from healthy cattle, sheep, and goats were aEPEC. The results of these reports also showed that aEPEC strains were more prevalent than tEPEC strains; this is consistent with our results. In present test, the percentage of aEPEC was significantly higher than tEPEC in AEEC when accounting for $82.09 \%$ (55/67), whereas the latter was only found in eight strains. In addition, we found that aEPEC was most frequently detected in all PCR positive strains compared to other categories. The findings of our research indicated that healthy dairy cows were a natural reservoir of aEPEC. STEC is an important pathogen recovered from different clinical isolates and even associated with hemolytic uremic syndrome (HUS) (1), and STEC strains of bovine origin have been detected elsewhere $(6,18)$. Rigobelo et al. (2006) (18) reported different countries had shown that $10-80 \%$ of cattle might carry STEC. However, in our study, a lower rate (1.98\%) of STEC isolation was found, and among the identified six STEC strains, four carried eaeA and stxl, two carried stxl alone, while none of the strains carried stx2. Similar results were described by some other reports in which stx 1 genes were more prevalent in bovine STEC isolates than stx2 genes $(7,19)$. ETEC strains are the major cause of diarrhea in human and in some animal species, especially in neonates $(20,21)$. ETEC causes diarrhea by producing enterotoxins heat-labile (lt), heatstable (st) or both (18). The two toxins were frequently found in diarrheal cases of humans, cattle and pigs, sometimes in healthy humans and pigs from different countries $(3,18,22$, 23). However, the distribution of ETEC in healthy cattle has been less noticed. As far as we know, Houser et al. (2008) (24) recently reported O-groups associated with ETEC in healthy lactating dairy cows of a Pennsylvania dairy herd when investigating phenotypic and genotypic diversity of $E$. coli in 10 cows. Blanco et al. (25) reported the prevalence of ETEC in $1 \%$ calves with diarrhea and $4 \%$ healthy controls. In present study, 6.93\% (7/101) cattle were confirmed to carry ETEC and 13 strains were positive for $s t$ and/or $l t$. The gene for $s t$ was detected from 10 strains and for $l t$ was from seven strains, four of them were positive for both, it seems that st was more prevalent. Similar result was described by Rigobelo et al. (2006) (18) in Brazil, for fecal samples from diarrheal dairy calves.

A wide range of serogroups in E. coli strains of bovine origin has already been reported either in disease cases or in healthy cattle, when some of them were only found in cattle and some were associated with humans (26). Among the serogroups detected in this survey, O2, O8, O103 and $\mathrm{O} 136$ belong to the prevalent serogroups in healthy cattle. For the rest serogroups, O10, O55, O125, O145, O149, and O159 were also identified from healthy cattle whereas with low proportions, especially, O55 was found only in one Japanese healthy cow (27). On the contrary, in our research, O149 was most frequent accounting for 25\% (21/84) and O55 was detected in $3.57 \%$ (3/84) strains. In addition, we identified four 
serogroups (O44, O78, O86, and O152) not reported in healthy cattle strains so far. Three of them have been reported in association with several diseases in human and cattle, namely, O44, O78 and O86 were detected from diarrheic patients (28), O78 was from septicemic calves (29), and O86 was from diarrheic calves (18). The majority of PCR-positive strains in present study belonged to serogroups previously found among isolates of cattle cases (i.e. gastrointestinal infections and diarrhea), and even found in patients with severe diseases, such as sudden infant death syndrome (SIDS), HUS, hemorrhagic colitis (HC), and urosepsis $(26,30,31,32)$. The result indicated that healthy cattle are the reservoir of $E$. coli strains associated with infections and diseases.

\section{CONCLUSION}

Our data confirm dairy cow as important asymptomatic carrier of E. coli strains pathogenic for humans, and as a major reservoir of atypical EPEC. To our knowledge, this is the first survey on the occurrence of these pathogenic strains in healthy cattle in China. Therefore, more epidemiological characteristics and virulence properties of these strains are necessary to be clarified in the future work.

\section{ACKNOWLEDGEMENTS}

This work was supported by the Major Special Project of National Dairy Industry of China (2006BAD04A15), the Key project of Natural Science Fund of Inner Mongolia, China (200607010403), and the Talent Fund of Inner Mongolia, China.

\section{REFERENCES}

1. Afset, J.E; Bergh, K; Bevanger, L. (2003). High prevalence of atypical enteropathogenic Escherichia coli (EPEC) in Norwegian children with diarrhoea. J. Med. Microbiol. 52, 1015-1019.

2. Aidar-Ugrinovich, L; Blanco, J; Blanco, M; Blanco, J.E; Leomil, L; Dahbi, G; Mora, A; Onuma, D.L; Silveira, W.D; Pestana de Castro, A.F.
(2007). Serotypes, virulence genes, and intimin types of Shiga toxinproducing Escherichia coli (STEC) and enteropathogenic E. coli (EPEC) isolated from calves in São Paulo, Brazil. Int. J. Food Microbiol. 115, 297-306.

3. Amar, C.F.L; East, C.L; Gray, J; Iturriza-Gomara, M; Maclure, E.A; McLauchlin, J. (2007). Detection by PCR of eight groups of enteric pathogens in 4, 627 faecal samples; re-examination of the English casecontrol Infectious Intestinal Disease Study (1993-1996). Eur. J. Clin. Microbiol. Infect. Dis. 26, 311-323.

4. Antikainen, J; Tarkka, E; Haukka, K; Siitonen, A; Vaara, M; Kirveskari, J. (2009). New 16-plex PCR method for rapid detection of diarrheagenic Escherichia coli directly from stool samples. Eur. J. Clin. Microbiol. Infect. Dis. 28, 899-908.

5. Bai, J.F; Shia, X.R; Nagarajaa, T.G. (2010). A multiplex PCR procedure for the detection of six major virulence genes in Escherichia coli O157:H7. J. Microbiol. Methods. 82, 85-89.

6. Beutin, L; Jahn, S; Fach, P. (2009). Evaluation of the 'GeneDisc' realtime PCR system for detection of enterohaemorrhagic Escherichia coli (EHEC) O26, O103, O111, O145 and O157 strains according to their virulence markers and their $\mathrm{O}-$ and $\mathrm{H}$-antigen-associated genes. J. Appl. Microbiol. 106, 1122-1132.

7. Blanco, M; Blanco, J; Blanco, J.E; Ramos, J. (1993). Enterotoxigenic, vertoxigenic, and necrotoxigenic Escherichia coli isolated from cattle in Spain. Am. J. Vet. Res. 54, 1446-1451.

8. Blanco, M; Schumacher, S; Tasara, T; Zweifel, C; Blanco, J.E; Dahbi, G; Blanco, J; Stephan, R. (2005). Serotypes, intimin variants and other virulence factors of eae positive Escherichia coli strains isolated from healthy cattle in Switzerland. Identification of a new intimin variant gene (eae- $\eta 2)$. BMC Microbiol. 5, 23.

9. Costa, M.M; Drescher, G; Maboni, F; Weber, S.S; Schrank, A; Vainstein, M.H; Schrank, I.S; Vargas, A.C. (2010). Virulence factors, antimicrobial resistance, and plasmid content of Escherichia coli isolated in swine commercial farms. Arq. Bras. Med. Vet. Zootec. 62, 30-36.

10. Fratamico, P.M; Yan, X.H; Liu, Y.H; DebRoy, C; Byrne, B; Monaghan, A; Fanning, S; Bolton, D. (2010). Escherichia coli serogroup O2 and $\mathrm{O} 28 \mathrm{ac} \mathrm{O}$-antigen gene cluster sequences and detection of pathogenic $E$. coli $\mathrm{O} 2$ and $\mathrm{O} 28 \mathrm{ac}$ by PCR. Can. J. Microbiol. 56, 308-316.

11. Ghanbarpour, R; Oswald, E. (2009). Characteristics and virulence genes of Escherichia coli isolated from septicemic calves in southeast of Iran. Trop Anim. Health. Prod. 41, 1091-1099.

12. Gillespie, B.E; Olive, S.P. (2005). Simultaneous detection of mastitis pathogens, Staphylococcus aureus, Streptococcus uberis, and Streptococcus agalactiae by multiplex real-time polymerase chain reaction. J. Dairy Sci. 88, 3510-3518.

13. Highet, A.R; Berry, A.M; Bettelheim, K.A; Goldwater, P.N. (2009). The frequency of molecular detection of virulence genes encoding cytolysin A, high-pathogenicity island and cytolethal distending toxin of 
Escherichia coli in cases of sudden infant death syndrome does not differ from that in other infant deaths and healthy infants. J. Med. Microbiol. $58,285-289$.

14. Hornitzky, M.A; Mercieca, K; Bettelheim, K.A; Djordjevic, S.P. (2005). Bovine feces from animals with gastrointestinal infections are a source of serologically diverse atypical enteropathogenic Escherichia coli and Shiga toxin-producing E. coli strains that commonly possess intimin. Appl. Environ. Microbiol. 71, 3405-3412.

15. Houser, B.A; Donaldson, S.C; Padte, R; Sawant A.A; DebRoy, C; Jayarao, B.M. (2008). Assessment of phenotypic and genotypic diversity of Escherichia coli shed by healthy lactating dairy cattle. Foodborne Pathog. Dis. 5, 41-51.

16. Hussein, H.S; Sakuma, T. (2005). Invited review: prevalence of Shiga toxin-producing Escherichia coli in dairy cattle and their products. $J$. Dairy Sci. 88, 450-465.

17. Johnson, J.R; Stell, A.L. (2000). Extended virulence genotypes of Escherichia coli strains from patients with urosepsis in relation to phylogeny and host compromise. J. Infect. Dis. 181, 261-272.

18. Kobayashi, H; Shimada, J; Nakazawa, M; Morozumi, T; Pohjanvirta, T; Pelkonen, S; Yamamoto, K. (2001). Prevalence and characteristics of Shiga toxin-producing Escherichia coli from healthy cattle in Japan. Appl. Environ. Microbiol. 67, 484-489.

19. Krause, G; Zimmermann, S; Beutin, L. (2005). Investigation of domestic animals and pets as a reservoir for intimin-(eae) gene positive Escherichia coli types. Vet. Microbiol. 106, 87-95.

20. Kwai, L.T; Ke, X.Y. (2009). Multiplex PCR for simultaneous detection of virulence Genes in Escherichia coli. Malaysian J. Sci. 28, 1-14.

21. López-Saucedo, C; Cerna, J.F; Villegas-Sepulveda, N; Thompson, R; Velazquez, R. F; Torres, J; Tarr, P.I; Estrada-García, T. (2003). Single multiplex polymerase chain reaction to detect diverse loci associated with diarrheagenic Escherichia coli. Emerg. Infect. Dis. URL: http://www.cdc.gov/ncidod/EID/vol9no1/01-0507.htm

22. Müller, D; Greune, L; Heusipp, G; Karch, H; Fruth, A; Tschäpe, H; Schmidt, M.A. (2007). Identification of unconventional intestinal pathogenic Escherichia coli isolates expressing intermediate virulence factor profiles by using a novel single-step multiplex PCR. Appl. Environ. Microbiol. 73, 3380-3390.

23. Nagy, B; Fekete, P.Zs. (1999). Enterotoxigenic Escherichia coli (ETEC) in farm animals. Vet. Res. 30, 259-284.

24. Nataro, J.P; Kaper, J.B. (1998). Diarrheagenic Escherichia coli. Cin. Microbiol. Rev. 11, 142-201

25. Orden, J.A; Ruiz-Santa-Quiteria, J.A; Cid, D; Díez, R; Martínez, S; De la Fuente, R. (2001). Quinolone resistance in potentially pathogenic and non-pathogenic Escherichia coli strains isolated from healthy ruminants. J. Antimicrob. Chemother. 48, 421-424.

26. Orden, J.A; Ruiz-Santa-Quiteria, J.A; García, S; Cid, D; De la Fuente, R. (1999). In vitro activities of Cephalosporins and Quinolones against Escherichia coli strains isolated from diarrheic dairy calves. Antimicrob. Agents. Chemother. 43, 510-513.

27. Rigobelo, E.C; Gamez, H.J; Marin, J.M; Macedo, C; Ambrosin, J.A. Ávila, F.A. (2006). Virulence factors of Escherichia coli isolated from diarrheic calves. Arq. Bras. Med. Vet. Zootec. 58, 305-310.

28. Rivera, F.P; Ochoa, T.J; Maves, R.C; Bernal, M; Medina, A.M; Meza, R; Barletta, F; Mercado, E; Ecker, L; Gil, A.I; Hall, E.R; Huicho, L; Lanata, C.F. (2010). Genotypic and phenotypic characterization of enterotoxigenic Escherichia coli (ETEC) strains isolated from Peruvian children. J. Clin. Microbiol. doi:10.1128/JCM.00644-10.

29. Rodriguez-Siek, K.E; Giddings, C.W; Doetkott, C; Johnson, T.J; Fakhr, M.K; Nolan, L.K. (2005). Comparison of Escherichia coli isolates implicated in human urinary tract infection and avian colibacillosis. Microbiology. 151, 2097-2110.

30. Walter, J; Hertel, C; Tannock, G.W; Lis, C.M; Munro, K; Hammes, W.P. (2001). Detection of Lactobacillus, Pediococcus, Leuconostoc, and Weissella species in human feces by using group-specific PCR primers and denaturing gradient gel electrophoresis. Appl. Environ. Microbiol. 67, 2578-2585.

31. Wells, J.G; Shipman, L.D; Greene, K.D; Sowers, E.G; Green, J.H; Cameron, D.N; Downes, F.P; Martin, M.L; Griffin, P.M; Ostroff, S.M; Potter, M.E; Tauxe, R.V; Wachsmuth, I.K. (1991). Isolation of Escherichia coli serotype O157:H7 and other Shiga-like-toxin-producing E. coli from dairy cattle. J. Clin. Mirobiol. 29, 985-989.

32. Yuste, M; Orden, J.A; De la Fuente, R; Ruiz-Santa-Quiteria, J.A; Cid, D; Martínez-Pulgarín, S; Domínguez-Bernal, G. (2008). Polymerase chain reaction typing of genes of the locus of enterocyte effacement of ruminant attaching and effacing Escherichia coli. Can. J. Vet. Res. 72, 444-448. 